\title{
Analisis Gaya Bahasa Dalam Cerpen "Maryam” Karya Afrion
}

\author{
Angle Widya Ningsih ${ }^{1}$, Gusni Hutabarat ${ }^{2}$, Juliani Rosmaida Hutahaean ${ }^{3}$, Junita \\ Karlina $^{4}$, Trisnawaty Hutagalung ${ }^{5}$ \\ E-mail: anglewidya1313@gmail.com¹, hutabarat0211@gmail.com², \\ hutahaeanjulirosmaida81@gmail.com ${ }^{3}$, junitakarlina1@gmail.com ${ }^{4}$ \\ Universitas Negeri Medan
}

\begin{abstract}
ABSTRAK
Penelitian ini menggunakan metode deskriptif-analitis, artinya data yang diperoleh dianalisis. Subjek penelitian adalah gaya bahasa cerpen Maryam karya Afrion. Kode sastra, tergambar pada ragam gaya bahasa penegasan, sindiran, perbandingan, dan gaya bahasa lainnya. Hasil analisis menunjukkan bahwa gaya bahasa penegasan terdapat majas hiperbola, polisendon, retorika, pararelisme, pleonasme, dan repetisi. Gaya bahasa perbandingan terdapat majas alegori, eufemisme, simbolik dan personifikasi. Sedangkan gaya bahasa sindiran terdapat majas sinisme, dan sarkasme. Dan ada gaya bahasa lainnya yaitu majas eklamasio. Di dalam cerpen Maryam, terdapat gaya bahasa yang bervariasi.
\end{abstract}

Kata Kunci: Gaya Bahasa, cerpen

\section{PENDAHULUAN}

Keberadaan karya sastra tidak terlepas dari adanya hubungan timbal balik antara pengarang, masyarakat dan pembaca. Hadirnya karya sastra di tengah-tengah masyarakat sebagai bentuk kreativitas penulis atau pengarang perlu mendapatkan perhatian dan dukungan dari pembaca. Karya sastra hadir dengan memberikan berbagai gambaran kehidupan yang dilalui atau realita yang terjadi di dalam kehidupan manusia. Karya tersebut ditulis dengan bermacam-macam gaya bahasa, seperti gaya bahasa perbandingan, pertentangan, sindirian, pertautan dan gaya bahasa perulangan.

Karya sastra cerpen yang menjadi bahan analisis adalah cerpen karya Afrion yang berjudul "Maryam". Cerpen ini berkisah tentang seorang janda dengan mertuanya. Dari kisah yang disampaikan dapat diketahui keegoisan, keserakahan, nafsu, dan kemarahan akan membawa ke dunia akhirat berujung dengan kata penyesalan. Kisah tersebut disusun dengan kalimat-kalimat yang rapi dan menarik. Gaya bahasa yang digunakan pun bervariasi. Beberapa hal diatas tersebut, mendorong peneliti untuk menganalisis penggunaan gaya bahasa penegasan, sindiran, perbandingan dan gaya bahasa lainnya di dalam cerpen Maryam, 
serta menganalisis penggunaan subjenis dari gaya bahasa penegasan, sindiran, perbandingan, dan gaya bahasa lainnya. Penelitian ini bertujuan untuk mengetahui penggunaan gaya bahasa di dalam cerpen Maryam serta untuk mengetahui penggunaan subjenis gaya bahasa tersebut. Sementara itu, kegunaan penelitian secara praktis diharapkan dapat menjadi masukan atau bahan informasi bagi peneliti selanjutnya atau pun mahasiswa lain yang ingin mendalami studi tentang Gaya Bahasa di dalam Cerpen dan secara akademis diharapkan dapat menjadi referensi tentang Gaya Bahasa dalam menjalankan tugas yang baik dan sebagai bahan informasi tentang Semantik.

Landasan teori gaya bahasa secara leksikologis, yakni: (i) pemanfaatan atau kekayaan bahasa seseorang dalam bertutur maupun menulis; (ii) pemakaian ragam tertentu untuk memperoleh efek-efek tertentu; (iii) keseluruhan ciri bahasa sekelompok penulis sastra; (iv) cara khas dalam menyatakan pikiran dan perasaan dalam bentuk tulisan dan lisan (Depdikbud, 1993:297). Gaya bahasa memang banyak dan biasanya dibicarakan di bidang sastra. Sebenarnya bukan soal gaya bahasa yang akan dipentingkan, tetapi makna kata atau kalimat yang menggunakan gaya bahasa tersebut yang perlu. Contohnya, kalau kita pergi ke kantin atau rumah makan, kemudian meminta 'kopi', pasti pelayan kantin atau rumah makan itu tidak akan menyodorkan kopi saja, tetapi kopi yang sudah diseduh dengan air panas, diberi gula, dan ditempatkan dalam cangkir atau gelas. Penyimpangan bahasa menurut Nurgiyantoro (2014, hlm. 316) khususnya deviasi semantis adalah bentuk penyimpangan bahasa yang terdapat pada semantis. Penyimpangan semantis yang terjadi dalam karya sastra dalam hal ini karya fiksi erat kaitannya dengan pemajasan atau gaya bahasa yang digunakan pengarang dalam karyanya. Hal ini diungkapkan Nurgiyantoro (2014, hlm. 317) bahwa pembicaraan deviasi semantis biasanya terkait dengan berbagai macam pemajasan.

Secara singkat dapat dikatakan bahwa gaya bahasa adalah cara mengungkapkan pikiran melalui bahasa secara khas yang memperlihatkan jiwa dan kepribadian menulis (pemakai bahasa). Sebuah gaya bahasa yang baik harus mengandung tiga unsur, yaitu kejujuran, sopansantun, dan menarik (Keraf, 2005, hlm. 113). Gaya bahasa dan kosakata mempunyai hubungan erat, hubungan timbal balik. Semakin kaya kosakata seseorang, kian beragam pulalah gaya bahasa yang dipakainya. Peningkatan pemakaian gaya bahasa jelas turut memperkaya kosakata pemakaiannya. Menurut Tarigan (2011, hlm. 6) ada sekitar 60 buah gaya bahasa yang akan termasuk ke dalam empat kelompok tersebut di atas; namun tidak secara menyeluruh akan dibahas di sini. Melainkan gaya bahasa yang sering muncul di dalam karya sastra sebagai berikut: 


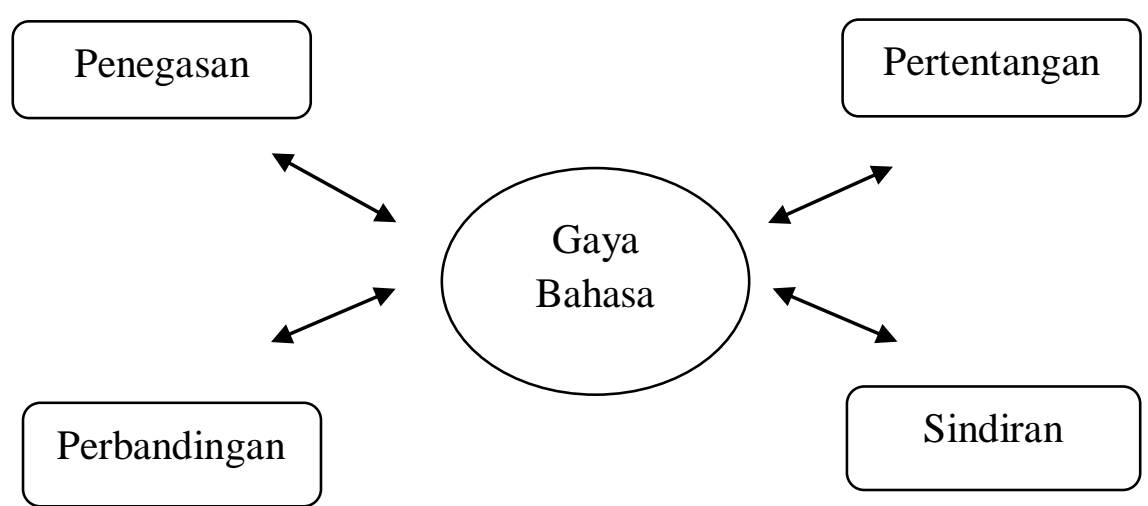

Jenis-jenis Gaya Bahasa dibagi menjadi empat, yaitu majas perbandingan, majas pertentangan, majas sindiran, majas penegasan, dan gaya bahasa yang lainnya. Pertama, Majas Perbandingan digunakan untuk menyandingkan atau membandingkan suatu objek dengan objek lain melalui proses penyamaan, pelebihan, ataupun penggantian. Majas ini terbagi menjadi beberapa jenis, yakni (a) Personifikasi, ialah gaya bahasa yang mana seakan menggantikan fungsi benda mati yang dapat bersikap layaknya manusia; (b) Metafora, ialah gaya bahasa yang meletakkan sebuah objek yang bersifat sama dengan pesan yang ingin disampaikan dalam bentuk ungkapan; (c) Asosiasi, yaitu membandingkan dua objek yang berbeda, namun dianggap sama dengan pemberian kata sambung yaitu: bagaikan, bak, ataupun, seperti; (d) Hiperbola, yaitu pengungkapan sesuatu dengan kesan berlebihan, bahkan hampir tidak masuk akal; (e) Eufemisme, yaitu gaya bahasa yang mengganti kata-kata yang dianggap kurang baik dengan padanan yang lebih halus; (f) Metonomia, yaitu menyandingkan merek atau istilah sesuatu untuk merujuk pada benda umum; (g) Simile, yaitu gaya bahasa yang hampir sama dengan asosiasi yang menggunakan kata hubungan bak, bagaikan, ataupun, seperti; hanya saja simile bukan membandingkan dua objek yang berbeda, melainkan ,menyandingkan sebuah kegiatan dengan ungkapan; (h) Alegori, yaitu gaya bahasa yaitu menyandingkan sesuatu objek dengan kata-kata kiasan; (i) Sinekdok, gaya bahasa terbagi menjadi dua bagia, yaitu sinekdok pars pro toto dan sinekdok totem pro parte. Sinekdok pars pro toto merupakan gaya bahasa yang menyebutkan sebagian unsur menampilkan keseluruhan sebuah benda. Sementara itu, sinekdok totem pro parte adalah kebalikannya, yakni gaya bahasa yang menampilkan keseluruhan untuk merujuk pada sebagian benda atau situasi; (j) Simbolik, yaitu gaya bahasa yang membandingkan manusia dengan sikap mahkluk hidup lainnya dalam ungkapan.

Kedua, majas pertentangan, yaitu gaya bahasa yang menggunakan kata-kata kias yang bertentangan dengan maksud asli yang penulis curahkan dalam kalimat tersebut. Jenis-jenis dapat dibagi menjadi beberapa subjenis, yakni: (a) Litotes, yaitu ungkapan untuk 
merendahkan diri, meskipun kenyataan yang sebenarnya adalah yang sebaliknya; (b) Paradoks, yaitu membandingkan situasi asli atau fakta dengan situasi yang kebalikannya; (c) Antitesis, yaitu memadukan pasangan kata yang artinya bertentangan; (d) Kontradiksi interminis, yaitu gaya bahasa yang menyangkal ujaran yang telah dipaparkan sebelumnya. Biasanya dengan konjungsi, seperti kecuali atau hanya saja.

Ketiga, majas sindiran, yaitu kata-kata yang memang tujuannya untuk menyindir seseorang ataupun perilaku dan kondisi. Jenis majas sindirin terbagi menjadi tiga subjenis, yakni: (a) Ironi, yaitu menggunakan kata-kata yang bertentangan dengan fakta yang ada; (b) Sinisme, yaitu menyampaikan sindiran secara langsung; (c) Sarkasme, yaitu menyampaikan sindiran secara kasar.

Keempat, majas penegasan, yaitu jenis gaya bahasa yang bertujuan meningkatkan pengaruh kepada pembacanya agar menyentujui sebuah ujaran ataupun kejadian. Majas ini dapat dibagi menjadi tujuh subjenis, yaitu: (a) Pleonasme, yaitu menggunakan kata-kata yang bermakna sama sehingga terkesan tidak efektif, namun memang sengaja untuk menegaskan sesuatu hal; (b) Repetisi, yaitu gaya bahasa ini mengulang kat-kata dalam sebuah kalimat; (c) Retorika, yaitu memberikan penegasan dalam bentuk kalimat tanya yang tidak perlu dijawab; (d) Klimaks, yaitu mengurutkan sesuatu dari tingkatan rendah ke tinggi; (e) Antiklimaks, yaitu berkebalikan dengan klimaks, gaya bahasa untuk antiklimaks menegaskan sesuatu dengan mengurutkan suatu tingkatan dati tinggi rendah; (f) Pararelisme, yaitu gaya bahasa ini biasa terdapat dalam puisi, yakni mengulang-ulang sebuah kata dalam berbagai defenisi yang berbeda. Jika pengulangannya ada di awal, disebut sebagai anfora. Namun, jika kata yang diulang ada di bagian akhir kalimat, disebut sebagai epifora; (g) Tautologi, yaitu menggunakan kata-kata bersinonim untuk menegaskan sebuah kondisi atau ujaran.

Kelima, gaya bahasa yang lain, diantaranya adalah sebagai berikut: (a) Gaya bahasa literasi, yaitu gaya bahasa yang menggunakan pengulangan konsonan pada awal kata secara urut; (b) Inversi, yaitu gaya bahasa yang mendahulukan predikat sebelum subjek dalam suatu kalimat; (c) Apofasis, yaitu gaya bahasa menegaskan sesuatu dengan cara seolah-olah menyangkal hal yang ditegaskan itu, (d) Kiasmus, yaitu gaya bahasa terdiri dari dua bagian, baik frasa maupun klausa, yang sifatnya sejajar namun dipertentangkan satu sama lain; (e) Elipsis, yaitu gaya bahasa yang menghilangkan unsur-unsur dalam suatu kalimat; (f) Pararima, yaitu gaya bahasa parirama merupakan gaya bahasa dalam bentuk pengulangan 
konsonan awal dan akhir dalam suatu kata atau bagian kata yang berlainan; (g) Eklamasio, yaitu gaya bahasa yang menggunakan kata seru.

Cerpen atau cerita pendek merupakan bentuk prosa negatif fiktif. Cerita cenderung padat dan langsung pada tujuannya dibandingkan dengan karya fiksi lainnya. Isi cerita pendek berpusat pada satu tokoh dan situasi tertentu di mana ada puncak masalah (klimaks) dan penyelesaiannya. Terdapat dua unsur cerpen yaitu unsur intrinsik dan ekstrinsik. Unsur intrinsik pada cerpen yaitu unsur pembentukan cerpen yang berasal dari cerpen itu sendiri. Beberapa hal yang termasuk di dalam unsur intrinsik, diantaranya adalah sebagai berikut: (a) Tema. Sumardjono (1984:57) berpendapat bahwa tema merupakan gagasan sentral pengarang yang mendasari penyusunan suatu cerita yang sekaligus menjadi catatan dari cerita itu; (b) Alur, yaitu seleksi peristiwa yang disusun dalam urutan waktu yang menjadi penyebab mengapa seseorang tertarik untuk membaca dan mengetahui kejadian yang akan datang; (c) Latar/setting. Tarigan (1984:134) mengemukakan bahwa latar adalah belakang fisik, unsur tempat, dan ruang dalam suatu cerita; (d) Tokoh. Aminuddin (1990: 126) berpendapat bahwa Penokohan adalah cara pengarang menampilkan tokoh dan pelaku; (e) Penokohan. Sayuti (2000:9-10) berpendapat bahwa tokoh dalam cerpen biasanya langsung ditujukan pada karakternya, artinya hanya ditujukan tahapan tertentu pengembangan karakter tokohnya; (f) Sudut pandang. Esten (1993:27) mengemukakan bahwa sudut pandang pencerita yaitu pengarang sebagai tokoh utama, pengarang sebagai tokoh samping, pengarang sebagai orang ketiga (berdiri di luar cerita) dan campur aduk, kadang-kadang masuk ke dalam cerita dan kadang-kadang di luar cerita; (g) Gaya bahasa. Situmorang (dalam Ambarita 2004:2) mengemukakan bahwa gaya bahasa adalah cara pengarang mengekpresikan atau melahirkan isi hatinya; dan (h) Amanat, yaitu pesan yang terkandung dalam sebuah cerita.

Sedangkan, unsur ekstrinsik pada cerpen adalah unsur pembentuk cerpen yang berasal dari luar. Beberapa yang termasuk di dalam unsur ekstrinsik adalah latar belakang masyarakat, latar belakang pengarang, dan nilai yang terkandung dalam cerpen. Ciri-ciri Cerpen, yaitu: (1) bentuk tulisan singkat, padat, dan lebih pendek dari novel; (2) sumber cerita dari kehidupan sehari-hari, baik pengalaman maupun orang lain, (3) tidak melukiskan seluruh kehidupan pelakunya karena mengangkat masalah tunggal atau sarinya saja; (4) tulisan kurang dari 10.000 kata; (5) habis dibaca sekali duduk dan hanya mengisahkan sesuatu yang berarti bagi pelakunya; (6) tokoh-tokohnya dilukiskan mengalami konflik sampai pada penyelesaiannya, (7) penggunaan kata-katanya sangat ekonomis dan mudah dikenal masyarakat, (8) menceritakan satu kejadian dari terjadinya perkembangan jiwa dan 
krisis, tetapi tidak sampai menimbulkan perubahan nasib; (9) meninggalkan kesan mendalam dan efek pada perasaan pembaca; (10) beralur tunggal dan lurus; (11) penokohannya sangat sederhana, singkat, dan tidak mendalam.

\section{METODE PENELITIAN}

Dalam penelitian ini menggunakan teknik observasi, meneliti gaya bahasa yang terdapat di dalam Cerpen “ Maryam”. Teknik analisis pengumpulan data yang digunakan peneliti dalam penelitian ini menggunakan teknik analisis kualitatif. Analisis data kualitatif merupakan bentuk analisis yang tidak menggunakan matematik, statistik, maupun bentukbentuk lainnya. Analisis data yang dilakukan terbatas pada teknik pengolahan data, kemudian peneliti melakukan penguraian dan penafsiran terhadap data-data yang telah diperoleh. Dalam hal analisis data kualitatif, Bogman (Sugiyono: 2013: 332) menyatakan Data analysis is the process of systematically searching and arranging the interview transcripts, field notes, and other materials that you accumulated to increase your own understanding of them and to enable you to present what you have discovered to others.

Analisis data pada penelitian ini dilakukan melalui beberapa langkah, yaitu (a) membaca dan mengamati cerpen; (b) menganalisis cerpen sesuai dengan gaya bahasa; (c) menarik kesimpulan sesuai dengan hasil analisis data yang dilakukan.

\section{HASIL DAN PEMBAHASAN}

Analisis Penggunaan Majas dan Subjenis Gaya Bahasa

\section{Majas Penegasan}

A. Hiperbola adalah gaya bahasa yang dipakai untuk melukiskan keadaan secara berlebihan.

1) Menggigil tubuh Maryam mendengar perkataan Angku Gadang. Menggigil artinya gemetar kerena kedinginan, demam, ketakutan.

2) Maryam berteriak sekuat tenaga. 
B. Polisendo

1) Maryam menjadi sendirian bekerja mengurus ladang karet, menderes getah, menyabit rumput liar dan mengumpulkan ranting-ranting membelah kayu seukuran yang ia bawa pulang.

2) Saban hari ketika Maryam selesai bekerja mengurus ladang pohon karet, menderes getah, menyabit rumput liar dan mengumpulkan ranting-ranting pohon di tengah ladang, Angku Gadang merayunya.

3) Tangan Angku Gadang semakin berani memegang wajah, tangan, dan mengeluselus rambut Maryam.

4) Maryam berusaha menjauh, melompati parit, kemudian pura-pura menyabit rumput di pinggir jalan besar.

5) Dicekam ketakutan. Setiap kali suami pulang dari menderes getah, ia akan selalu dimarahi, dicurigai, bahkan sering menerima tamparan kalau ia membantah.

C. Retorika

1. Apa kata penduduk kampung kalau tahu ia kawin lagi dengan mertua sendiri?

2. Tidakkah itu akan menyakitkan arwah suaminya?

3. Antara perasaan bersalah dan dosanya menghujamkan parang ke Tubuh Angku Gadang, sudah matikah ia?

D. Paralelisme

1. Dengan membabi-buta parang itu dihujamkan ketubuh Angku Gadang, berkali-kali sampai lelaki durjan aitu terjerembab ke tanah, lunglai bersimbah darah.

E. Pleonasme

1. Maryam sadar, ia kebingungan sendiri.

F. Repetisi

1. Sampai serak suaranya, sampai ia lemas tak berdaya. 


\section{Majas Perbandingan}

A. Alegori

1. Kalau ia tidak mau mati kelaparan dengan wajah keriput dan kurus kering.

B. Eufemisme

1. Ia harus bekerja keras mencari nafkah untuk menyambung hidupnya.

2. Tapi untunglah ia segera sadar menghadapi laki-laki seperti itu, harus pandai memutar haluan.

3. Sebaliknya, dengan perasaan dongkol Angku Gadang menjauh meninggalkan Maryam bersama Nek Suti menuju ke arah lain.

C. Simbolik

Apakah ganti tikar atau menjaga kesinambungan hubungan keluarga, Maryam tetap menolak.

D. Personifikasi

1. Ibarat buah mentah yang masak di karbid, manisnya akan lain jika dibandingkan dengan buah yang masak di pohon.

\section{Gaya Bahasa Sindiran}

A. Sinisme

1. Kalau bukan karena mertua, sudah diludahinya Angku Gadang.

2. Maryam menarik nafas, untuk kali ini selamatlah ia dari perlakuan Angku Gadang yang kasar.

3. "Mereka saja yang mata keranjang, Nek"

B. Sarkasme

1. "Ah! Persetan dengan mertua."

\section{Gaya bahasa lainnya}

A. Eklamasio

1. Jangan sembarangan menerima orang!

2. "Masih banyak perempuan lain, pak! Kenapa harus saya!" 
3. "Aku tidak mau kawin, pak !"

4. "Tidak"!

5. "Aku tidak mau kalau kau kawin dengan laki-laki lain, Maryam!"

6. "Aku tidak akan kawin, pak! Tidak akan kawin dengan siapapun!"

7. "Lima tahun aku menunggu, sekarang kesabaranku sudah habis!"

8. Malu pak! Aku malu! Jangan paksa aku kawin dengan mertuaku sendiri”

\section{SIMPULAN}

Berdasarkan hasil analisis yang telah dilakukan terhadap cerpen Maryam dapat disimpulkan bahwa isi cerita dalam cerpen yang dianalisis mengandung majas penegasan. Majas perbandingan terdapat gaya bahasa hiperbola, polisendon, retorika, paralelisme, pleonasme, dan repetisi. Majas perbandingan terdapat gaya bahasa alegori, eufemisme, simbolik, dan fersonifikasi. Majas sindiran terdapat gaya bahasa yaitu sinisme, dan sarkasme. Gaya bahasa lainnya terdapat eklamasio.

\section{DAFTAR PUSTAKA}

Keraf, Gorys. 2005. Diksi dan Gaya Bahasa. Jakarta: PT. Gramedia.

Nurgiyantoro, Burhan. 2014. Stilistika. Yogyakarta: Gadjah Mada University Press.

Sugiyono. 2010. Metode Penelitian Pendidikan Pendekatan Kuantitatif, Kualitatif, dan $R$ \& $D$. Bandung: Alfabeta.

Tarigan, Henry Guntur. 2011. Pengajaran Kosa Kata. Bandung: Angkasa.

Teeuw, Andreas. 1984. Sastera dan Ilmu Sastera. Bandung: Pustaka Jaya.

Wellek, Rene \& Austin Warren. 2014. Teori Kesusastraan. Jakarta: PT. Gramedia Pustaka Utama. 